\title{
The Middle Paleolithic Occupations of Mutzig-Rain (Alsace, France)
}

\author{
Héloïse Koehler ${ }^{1}$, Fabio Wegmüller², Benjamin Audiard³, \\ Patrick Auguste ${ }^{4}$, Jean-Jacques Bahain ${ }^{5}$, Hervé Bocherens ${ }^{6,7}$, \\ Simon Diemer ${ }^{8}$, Frank Preusser ${ }^{9}$, Christine Pümpin², \\ Noémie Sévêque ${ }^{10}$, Emmanuelle Stoetzel ${ }^{5}$, Olivier Tombret ${ }^{11}$, \\ Patrice Wuscher 12
}

1 Archéologie Alsace and UMR 7044, “Préhistoire de l’Europe moyenne," France

2 Integrative Prehistory and Archaeological Science (IPAS), University of Basel, Switzerland

3 CNRS, CEPAM, UMR 7264, Université Côte d'Azur, Nice, France

4 CNRS, UMR 8198, “Evo-Eco-Paléo," Université de Lille, France

5 Muséum National d’Histoire Naturelle, UMR 7194, “Histoire naturelle de l'Homme préhistorique," MNHN-CNRS-UPVD, France

6 Department of Geosciences, Biogeology, University of Tübingen, Germany

7 Senckenberg Centre for Human Evolution and Palaeoenvironment, Tübingen, Germany

8 UMR 7044, Archimède, Université de Strasbourg, France

9 Institute of Earth and Environmental Science, University of Freiburg, Germany

10 GéoArchPal-GéoArchÉon SARL, UMR 7044, Archimède, Équipe Préhistoire de l'Europe moyenne, MISHA, Université de Strasbourg, France

11 Musée de l'Homme, UMR 7194, “Histoire naturelle de l'Homme préhistorique," UMR 7209, "Archéozoologie, archéobotanique: sociétés, pratiques et environnements," France

12 Laboratoire Image Ville Environnement, UMR 7362, Université de Strasbourg, CNRS, France

\begin{abstract}
The Paleolithic site of Mutzig, discovered by chance in 1992 (Sainty 1992), has been the focus of several excavations since 2009. Located in Alsace (Bas-Rhin, France), it is presently one of only a handful of sites reliably attributed to the Middle Paleolithic in this area, thus providing rare evidence for a zone still relatively unknown for Early Prehistoric remains. The excellent preservation of the remains and the long stratigraphic sequence, with 6 to 8 in situ archaeological levels, make Mutzig a potential reference site for environmental and behavioral analyses for the Middle Paleolithic of the region. At least four archaeological levels contain burnt elements, and one level features a hearth structure. Taken together, the
\end{abstract}


archaeological material, which is abundant in each of the different layers, forms an assemblage of more than 3000 faunal remains and more than 1500 lithic artifacts.

Analyses of this site provide valuable insights into the environment and Neandertal ways of life in Alsace. We provide here only general results, with more detailed descriptions of the lithic and faunal remains presented in Diemer (this volume) and Sévêque (this volume). The faunal remains recovered from the human occupations in Levels 5 and 7 reflect the same relatively cold steppe-like environmental context and include reindeer, woolly mammoth, steppe horse, steppe bison and woolly rhinoceros. Small vertebrates also indicate a cold climate, though not related to the Pleniglacial. Confirmed isotopic data, from oxygen and carbon isotope measurements of horse and mammoth teeth, indicate temperatures lower than those of today and an open environment. Levels 9 and 10 , however, tend to reveal a more temperate climate. The available $\mathrm{OSL}$ and ESR/U-series dates place the Mutzig occupations within the Early Weichselian Glacial (MIS 5, ca. $90,000 \mathrm{BP}$ ), an attribution which biometric analyses and the large and small fauna record tend to corroborate (Koehler et al. 2016a).

\section{RÉSUMÉ}

Le site paléolithique moyen de Mutzig constitue un gisement exceptionnel pour la région du Rhin supérieur. Localisé en Alsace (Bas-Rhin) et découvert fortuitement en 1992 (Sainty, 1992), il fait l'objet de recherches systématiques depuis 2009 dans le cadre d'une fouille programmée. Ce gisement offre une très bonne conservation des vestiges archéologiques, puisque éléments lithiques, faune, microfaune, charbons et structures de combustion y sont bien préservés et présents en grande quantité.

Localisés sous un abri sous-roche en grès rose aujourd'hui effondré, six à huit niveaux archéologiques en place ont été pour le moment mis en évidence, le substrat n'ayant pas été encore atteint. Ils sont tous rattachables au Paléolithique moyen, plus précisément au Début Glaciaire Weichselien, datés par OSL et ESR/U-Th autour de 90000 ans. Mais si les niveaux 5 et 7 présentent un signal paléoenvironnemental de steppe froide et sèche, les niveaux 9 et 10 tendraient à montrer un climat plus tempéré et des zones boisées mieux représentées. Bien qu'ils exposent une même ambiance technique pour l'industrie lithique, des différences sont perceptibles. Le développement de la fouille planimétrique couplé aux approches pluridisciplinaires (anthracologie ; palynologie ; micromorphologie ; sédimentologie ; pétrographie ; archéozoologie ; microfaune ; analyses isotopiques ; études lithiques ; études des foyers) permet des premières reconstitutions des occupations néandertaliennes (Koehler et al., 2016a). Le présent article traite des données générales, les présentations détaillées des restes lithiques et faunistiques font l'objet d'articles spécifiques (Diemer, ce volume ; Sévêque, ce volume).

\section{ZUSAMMENFASSUNG}

Die mittelpaläolithische Fundstelle Mutzig “Rain" liegt im Elsass (Département Bas-Rhin, F) und wurde 1992 (Sainty, 1992)bei Umbauarbeiten zufällig entdeckt. Seit 2009 wird sie im Rahmen von systematischen Grabungskampagnen 
erforscht. Die Fundstelle lag ursprünglich unter einem Felsdach aus Buntsandstein, welches aber schon in prähistorischer Zeit teilweise eingestürzt und heute nicht mehr sichtbar ist. Insgesamt sind zurzeit sechs or acht archäologische Schichten bekannt. Der natürliche Felsgrund wurde bisher nicht erreicht und deshalb ist die vertikale Ausdehnung der Fundschichten nicht bekannt. Das reiche Fundmaterial ist sehr gut erhalten und setzt sich vorwiegend aus Steinartefakten, Faunenresten, Mikrofauna und Holzkohlen zusammen. Mehrere gut erhaltene Feuerstellen konnten ebenfalls dokumentiert werden.

Alle Funde können dem Mittelpaläolithikum zugewiesen werden, die absoluten Datierungen (OSL, sowie ESR/U-TH) liegen alle in einem Zeitraum um 90'000 Jahre vor heute und zeigen eine chronologische Stellung zu Beginn der letzten Eiszeit (Weichsel bzw. Würmkaltzeit).

Auch wenn das Fundmaterial aller Fundschichten grosse Ähnlichkeiten hinsichtlich der Umweltbedingungen aufweist und auch die Steinartefakte viele Gemeinsamkeiten zeigen, sind innerhalb der Schichtabfolge Unterschiede erkennbar.

Eine ausgedehnte Flächengrabung und die Resultate der interdisziplinären Zusammenarbeit erlauben uns erste Einblicke in die Besiedelung der Fundstelle zur Zeit der Neandertaler. Neben der Analyse der Steingeräte und der Feuerstellen wird das Fund- und Probenmaterial auch von Spezialisten der Archäozoologie, Mikrofauna, der Geoarchäologie (Mikromorhologie, Sedimentologie und Petrogtraphie), Anthrokologie, Palynologie und der Isotopenanalyse bearbeitet (Koehler et al., 2016a).

\section{HISTORY OF DISCOVERIES}

The site of Mutzig is located in Alsace, due west of Strasbourg. It lies in the heart of the Rhine Valley in what was probably a strategic location during the great animal migrations of the Ice Age (Fig. 1: 1). More precisely, the site is located at the foot of the Bruche Valley. The Bruche is a tributary of the Rhine that rises in the Vosges, with the site situated at the very point where the valley narrows before opening onto the plain. This topographical position could have been exploited by Neanderthals for hunting, particularly since this was originally a marshy area and remained so until drainage works were undertaken in the early 1900s.

A number of early discoveries in the neighboring commune of Greswiller are worth mentioning. At the end of the 19th and the beginning of the 20th century deposits of animal bones were found during railway construction works (Forrer 1930; Fig. 1: 2). The remains were found at the foot of a rocky spur, facing the site of Mutzig, exactly at the narrow point of the valley mentioned above. In the 1920s a follow-up study of the site carried out by Robert Forrer identified the remains of Pleistocene fauna such as mammoth, rhinoceros and horse. No anthropogenic remains were found, although it is possible that they simply were not identified at the time.

The site of Mutzig itself was discovered in 1992, directly opposite the earlier discoveries. While digging in his garden, a local man uncovered a 
Koehler, Wegmüller, Audiard, et al.

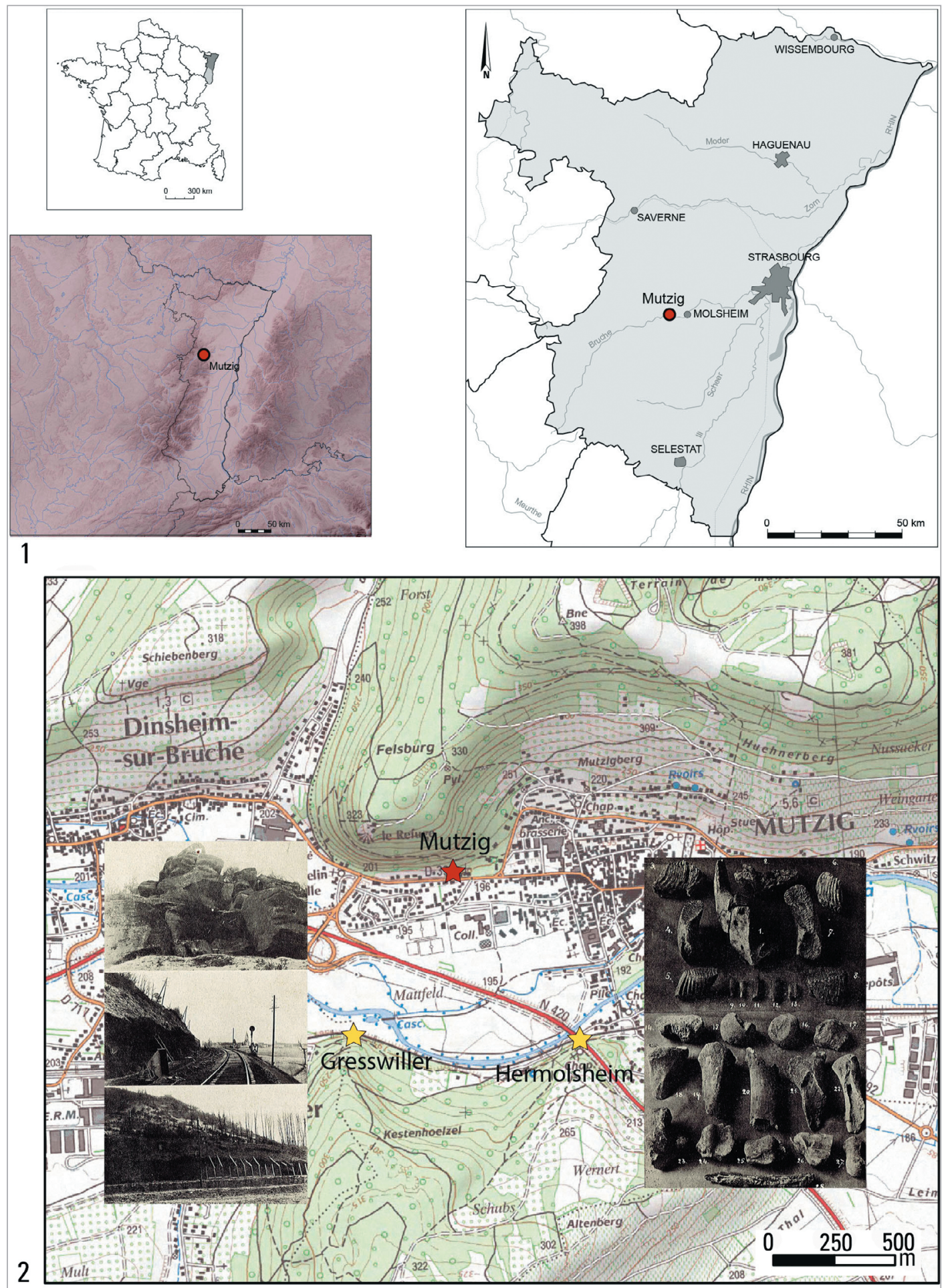


Fig. 1 (left).

Map showing the location of Mutzig and the earlier discoveries at Hermolsheim and Gresswiller (DAO: E. Cornet and H. Koehler; photographs after Forrer 1930). 1: Location of the site of Mutzig and those of Achenheim; 2: Earlier discoveries at Hernolsheim and Gresswiller revealed during the digging of the railway.

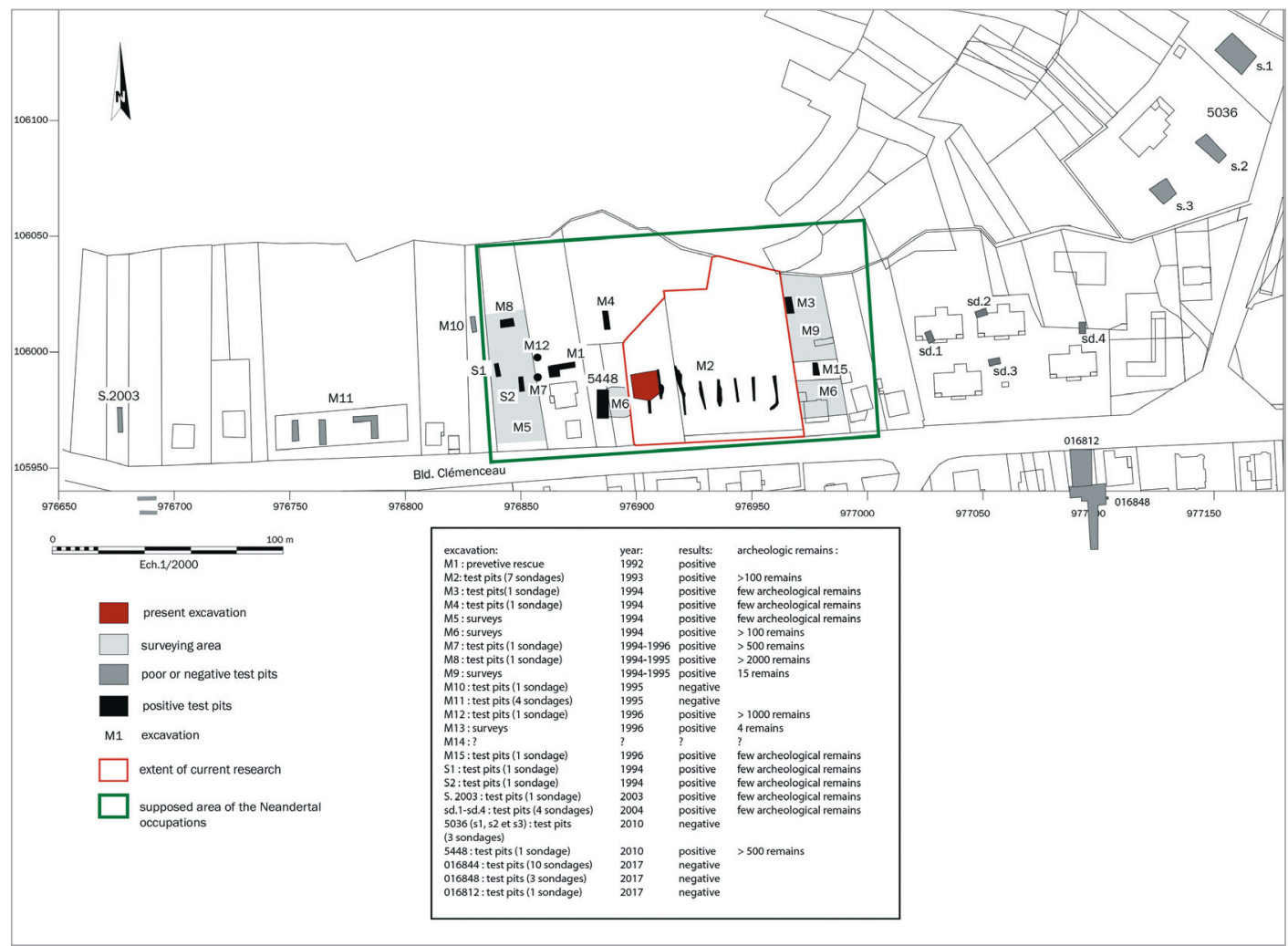

number of lithic artifacts and large animal bones, including those of Mammoth and rhinoceros.

Following these discoveries, the plots located next to these discoveries, which were earmarked for development, were archaeologically tested by Jean Sainty in 1993 (Sainty 1993; Sainty et al. 1994 and Koehler et al. 2016a; Fig. 2). All of the test trenches yielded evidence for Middle Paleolithic levels. None of the trenches reached the natural bedrock as excavation was generally stopped once anthropogenic material was found. In light of these positive results, the two plots were purchased by the public authority in 2007 and construction plans were abandoned.

Over a period of several years, a program of archaeological testing, surveying and assessment was carried out in this communal area (Sainty et al. 1996). This allowed the extent of the Paleolithic occupation to be delimited within an area of about $5000 \mathrm{~m}^{2}$. Current excavations involve
Fig. 2 (above).

Map showing position of the test pits and excavations conducted at the base of Felsbourg Cliff. (T. Hauck, modified). 


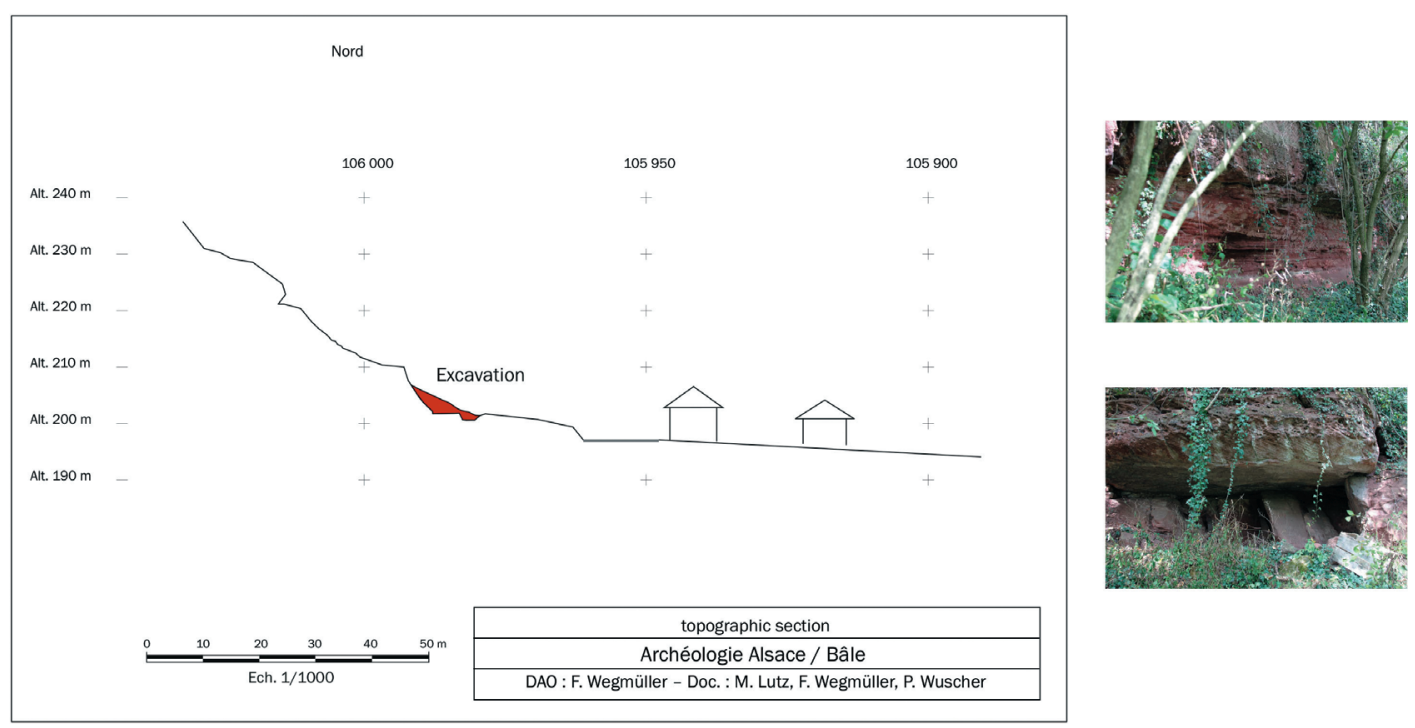

Fig. 3.

Topographic section from the slope to the location of the systematically excavated zone and examples of existing Felsbourg rockshelters (F. Wegmüller). an area of $50 \mathrm{~m}^{2}$. Excavations began in 2009, with the first season of fieldwork focused on re-opening the trenches dug by Jean Sainty in the 1990s (Detrey et al. 2009). The excavations were then extended progressively from both sides of this trench (Koehler et al. 2013, 2016b).

\section{LOCATION}

The site of Mutzig is located at the foot of Felsbourg Cliff. This south-facing cliff features a number of natural steps, which could have been an added attraction for Neanderthal populations.

However, the principal attraction of the cliff is the presence of a number of rockshelters that are still visible today but which are very vulnerable to collapse due to the poor quality of the sandstone blocks from which they are formed (Fig. 3). Neanderthal groups regularly occupied the shelters, moving from one to another when the roof collapsed. Excavation of the shelters has involved moving large blocks of sandstone in order to reach the underlying archaeological levels. It is probably this "sealing" of the levels by stone slabs that ensured their preservation as the overlying material provided protection from erosion.

\section{HYPOTHESIS OF ROOF COLLAPSE}

Several hypotheses can be advanced regarding the various phases of roof collapse in the shelter (Fig. 4). The earliest occupations were revealed during test trenching. At the time of writing it has not yet been ascertained whether these occupations took place under a shelter with a larger roof which subsequently collapsed or if they occurred on one of the natural steps, that is to say, at the foot of the cliff. 


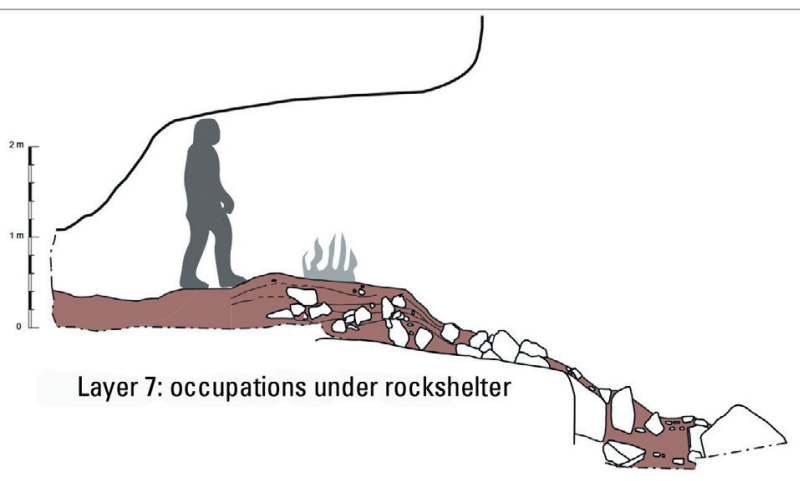

Fig. 4.

Various phases of roof collapse within the shelter

(Drawing: P. Wuscher).
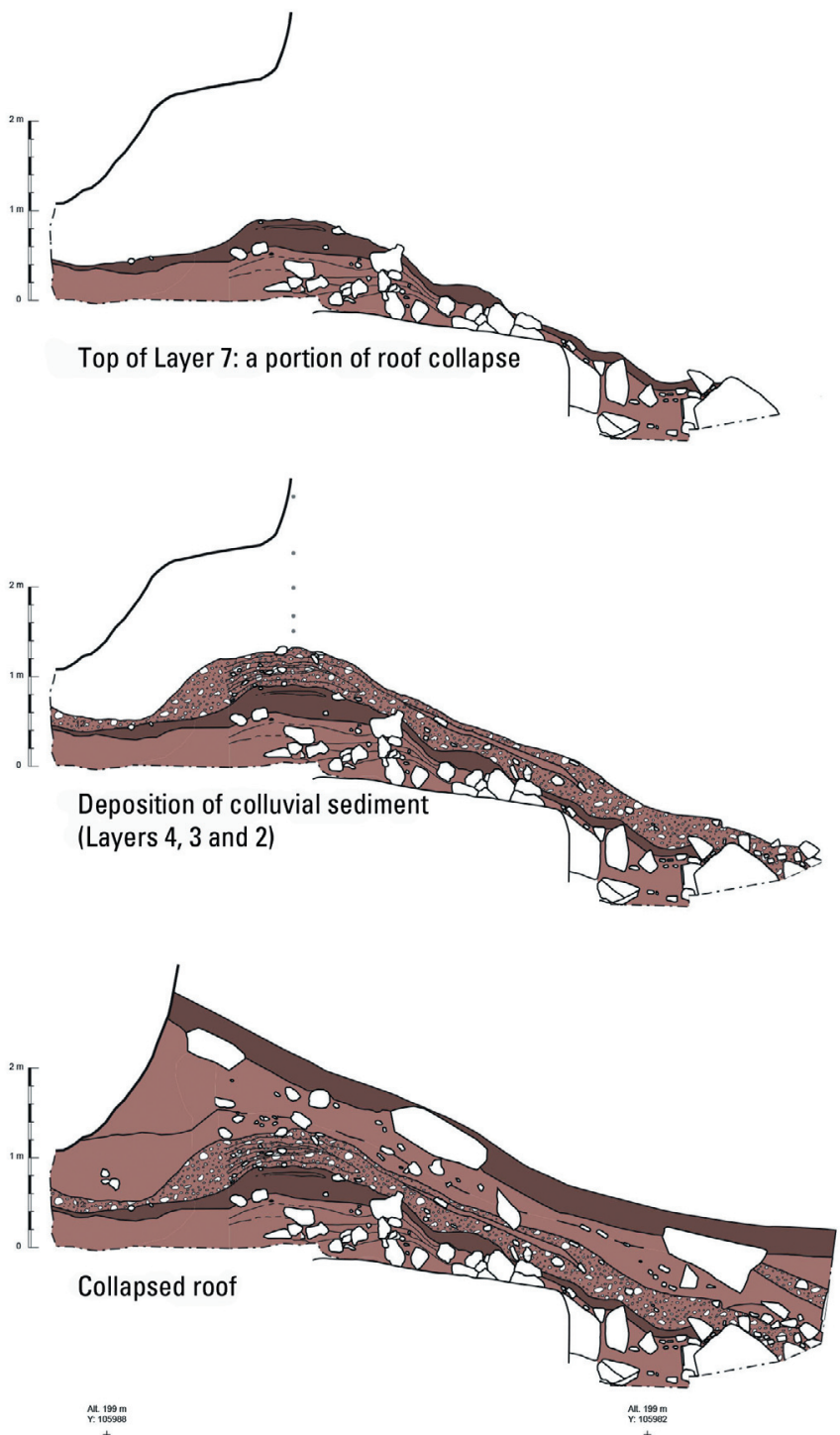
Greater certainty surrounds a number of later occupations that took place under a shelter with a relatively large roof that has subsequently collapsed. The final occupation phases occurred under a much reduced overhang. We can observe a final collapse of the overhang that left the shelter unusable and sealed the archaeological layers. We then see deposition of colluvial sediments originating from the upper part of the cliff.

\section{AN IMPORTANT WELL-PRESERVED MIDDLE PALEOLITHIC SEQUENCE}

Several archaeological layers, all dating to the Middle Paleolithic, can be clearly identified. We can identify four upper layers, which are in fact modified layers, resulting from gravitational forces and probably originating from the destruction of a shelter located at a higher level (Fig. 5). These levels are therefore colluvial in nature. They can be attributed to the Middle Paleolithic but they are of limited interest here since we cannot date them precisely and are greatly disturbed. As a result, we will not consider them further.

In contrast, six archaeological levels can be identified in situ under the rockshelter. These levels themselves probably represent the effacement and superimposition of several repeated occupations.

Finally, archaeological testing has revealed the presence of at least two or three earlier levels which were located either within a larger overhang or at the foot of the cliff. It should be pointed out that our excavations have not yet reached the natural bedrock, making it therefore possible that even earlier layers will be discovered in the future.

These levels belong to the Middle Paleolithic, and a series of OSL and ESR-Uranium-Thorium dates have been obtained for the entire sequence (Tables 1 and 2). All of the dates obtained are centered on 90,000 years BP, thus placing the levels at the beginning of the Wechselian Glaciation.

Table 1.

OSL dates (F. Preusser). $\mathrm{W} \%=15 \pm 5$, all ages are CAM, N $48^{\circ} 32^{\prime}$ E $7^{\circ} 26^{\prime}, 215 \mathrm{~m}$, $\mathrm{K}=12.5 \pm 0.5$ Studies of the faunal, microfaunal and charcoal remains confirm this attribution, which indicates a rapid build-up of material, as all occupations of the site took place within a maximum time period of $10,000-$ 15,000 years.

\begin{tabular}{|c|c|c|c|c|c|c|c|c|c|c|}
\hline $\begin{array}{l}\text { Lab } \\
\text { Code }\end{array}$ & Couche & $\begin{array}{c}\text { Depth } \\
\text { (cm) }\end{array}$ & $\mathbf{n}$ & od. & K (\%) & Th (ppm) & U (ppm) & D (Gy ka-1) & $D_{e}(G y)$ & Age (ka) \\
\hline Mu16-1F & C3 & 230 & 12 & 0.11 & $1.99 \pm 0.02$ & $3.15 \pm 0.19$ & $0.71 \pm 0.05$ & $2.92 \pm 0.10$ & $239.7 \pm 8.1$ & $82 \pm 4$ \\
\hline Mu16-2F & C5 & 240 & 12 & 0.13 & $1.91 \pm 0.02$ & $3.94 \pm 0.22$ & $0.92 \pm 0.06$ & $2.94 \pm 0.12$ & $264.5 \pm 10.3$ & $90 \pm 5$ \\
\hline Mu16-3F & $\mathrm{C7C1}$ & 270 & 12 & 0.08 & $2.11 \pm 0.02$ & $3.72 \pm 0.15$ & $0.89 \pm 0.03$ & $3.07 \pm 0.13$ & $248.9 \pm 6.6$ & $81 \pm 4$ \\
\hline Mu16-4F & C9 & 190 & 12 & 0.12 & $1.50 \pm 0.01$ & $3.75 \pm 0.16$ & $1.06 \pm 0.06$ & $2.63 \pm 0.07$ & $276.2 \pm 10.6$ & $105 \pm 5$ \\
\hline Mu16-5F & C10 & 250 & 12 & 0.10 & $2.00 \pm 0.02$ & $3.91 \pm 0.10$ & $0.89 \pm 0.08$ & $2.99 \pm 0.11$ & $248.4 \pm 8.1$ & $83 \pm 4$ \\
\hline
\end{tabular}




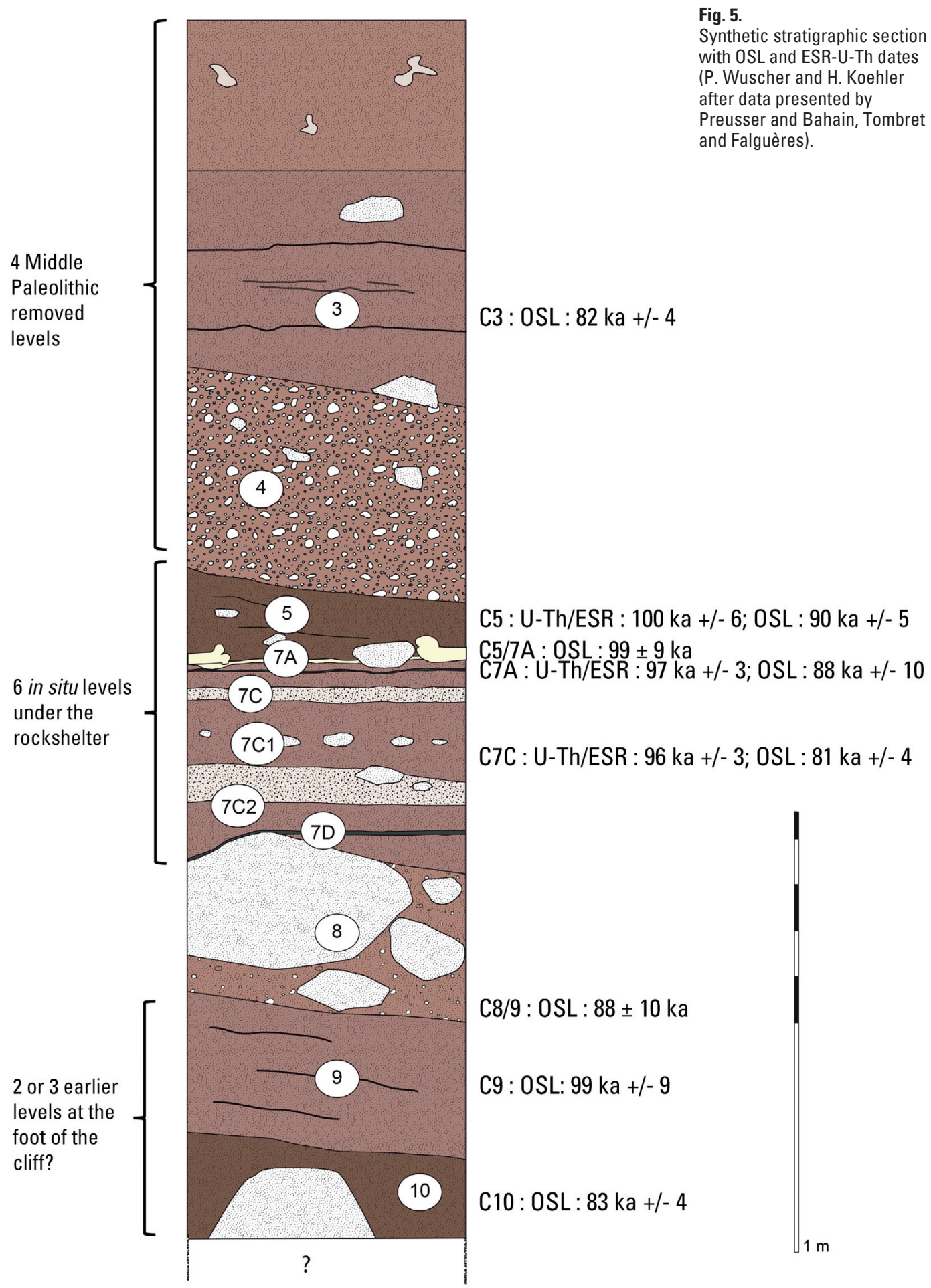




\begin{tabular}{|c|c|c|c|c|c|c|c|c|}
\hline Echantillon & Tissu & $\begin{array}{l}\text { Paléodose } \\
\text { (Gy) }\end{array}$ & $\begin{array}{c}\text { Paramètre } \\
\text { d'incorporation } \\
\text { n (AU) }\end{array}$ & $\begin{array}{c}D_{\alpha} \text { interne } \\
\text { moyenne * } \\
\text { ( } \mu \text { Gy/an) }\end{array}$ & $\begin{array}{l}D_{B} \text { externe } \\
\text { moyenne } \\
\text { ( } \mu \text { Gy/an) }\end{array}$ & $\begin{array}{c}D(\gamma+\operatorname{cosm}) \\
\text { externe** } \\
\text { ( } \mu \text { Gy/an) }\end{array}$ & $\begin{array}{c}D_{a} \\
\text { moyenne } \\
\text { ( } \mu G y / a n)\end{array}$ & $\begin{array}{c}\text { Age } \\
\text { RPE/U-Th**** } \\
\text { (AU) (ka) }\end{array}$ \\
\hline \multirow{3}{*}{$\begin{array}{c}\text { MU1301 } \\
\text { (OFA 198, } \\
\text { 06-C5 UP5) }\end{array}$} & émail & \multirow{3}{*}{$\begin{array}{c}222.74 \pm \\
10.41\end{array}$} & $-0.0380 \pm 0.0034$ & \multirow{3}{*}{$274 \pm 6$} & \multirow{3}{*}{$1149 \pm 22$} & \multirow{3}{*}{$807 \pm 44$} & \multirow{3}{*}{$2230 \pm 49$} & \multirow{3}{*}{$100 \pm 6$} \\
\hline & dentine & & $-0.0338 \pm 0.0043$ & & & & & \\
\hline & cément & & $-0.0112 \pm 0.0003$ & & & & & \\
\hline \multirow{3}{*}{$\begin{array}{l}\text { MU1302 } \\
\text { (OFA 326, } \\
\text { M8-C7 UP3) }\end{array}$} & émail & \multirow{3}{*}{$171.36 \pm 4.87$} & $-0.0399 \pm 0.0021$ & \multirow{3}{*}{$313 \pm 4$} & \multirow{3}{*}{$593 \pm 7$} & \multirow{3}{*}{$858 \pm 46$} & \multirow{3}{*}{$1764 \pm 47$} & \multirow{3}{*}{$97 \pm 3$} \\
\hline & dentine & & $-0.0309 \pm 0.0021$ & & & & & \\
\hline & cément & & $-0.0115 \pm 0.0001$ & & & & & \\
\hline \multirow{3}{*}{$\begin{array}{l}\text { MU1303 } \\
\text { (OFA 466, } \\
\text { C7A) }\end{array}$} & émail & \multirow{3}{*}{$179.16 \pm 4.19$} & $-0.0078 \pm 0.0008$ & \multirow{3}{*}{$284 \pm 3$} & \multirow{3}{*}{$731 \pm 10$} & \multirow{3}{*}{$858 \pm 46$} & \multirow{3}{*}{$1873 \pm 10$} & \multirow{3}{*}{$96 \pm 3$} \\
\hline & dentine & & $-0.0083 \pm 0.0011$ & & & & & \\
\hline & cément & & $-0.0091 \pm 0.0010$ & & & & & \\
\hline
\end{tabular}

\section{Table 2.}

Paleodose, incorporation parameters, and contributions of the various types of radiation to the annual dose rate and ESR/U Th dates obtained on samples analyzed from Mutzig (Bas Rhin) (Bahain, Tombret et Falguières, Koehler et al. 2016b).
In addition, the state of preservation on the site is very good with significant quantities of remains having survived. These have allowed us to undertake detailed paleoenvironmental analyses (Koehler et al. 2016a; Audiard, Bocherens, Richard, Sévêque, Stoetzel in Koehler et al. 2016b; Stoetzel and Montuire 2016; Stoetzel et al. 2016; Sévêque 2017).

We can therefore say that, overall, and especially in Layers 5 and 7, the environment was characterized by cold, steppe-like conditions in which mammoth, reindeer and horse thrived. The record also indicates the presence of woodland refuges. Estimated mean annual temperatures varied between $3^{\circ} \mathrm{C}$ and $6^{\circ} \mathrm{C}$ (against around $9.7^{\circ} \mathrm{C}$ for the Strasbourg region today), reflecting a cool, dry climate but not a fully glacial one.

The combination of paleoenvironmental data allows us to identify small differences between layers. Thus, two phases of thawing can be discerned: one at the top of the sequence and the other at its base (Layers 9 and 10). It remains to be seen if these thaws can be correlated either to the Early Glacial interstadials or to the Eemian interglacial. This would allow us to anchor the chronology of the various occupations.

\section{RESULTS}

The main results from the principal excavated layers will be outlined blow, starting at the most recent levels and working back to the oldest. More detailed data regarding the faunal remains and lithics are presented elsewhere (Sévêque and Diemer, this volume).

\section{Layer 5}

Layer five is the youngest of the in situ layers and is the one that has been most extensively excavated (Fig. 6). The occupations, protected by a reduced overhang, occurred beneath the shelter itself and also on the talus 


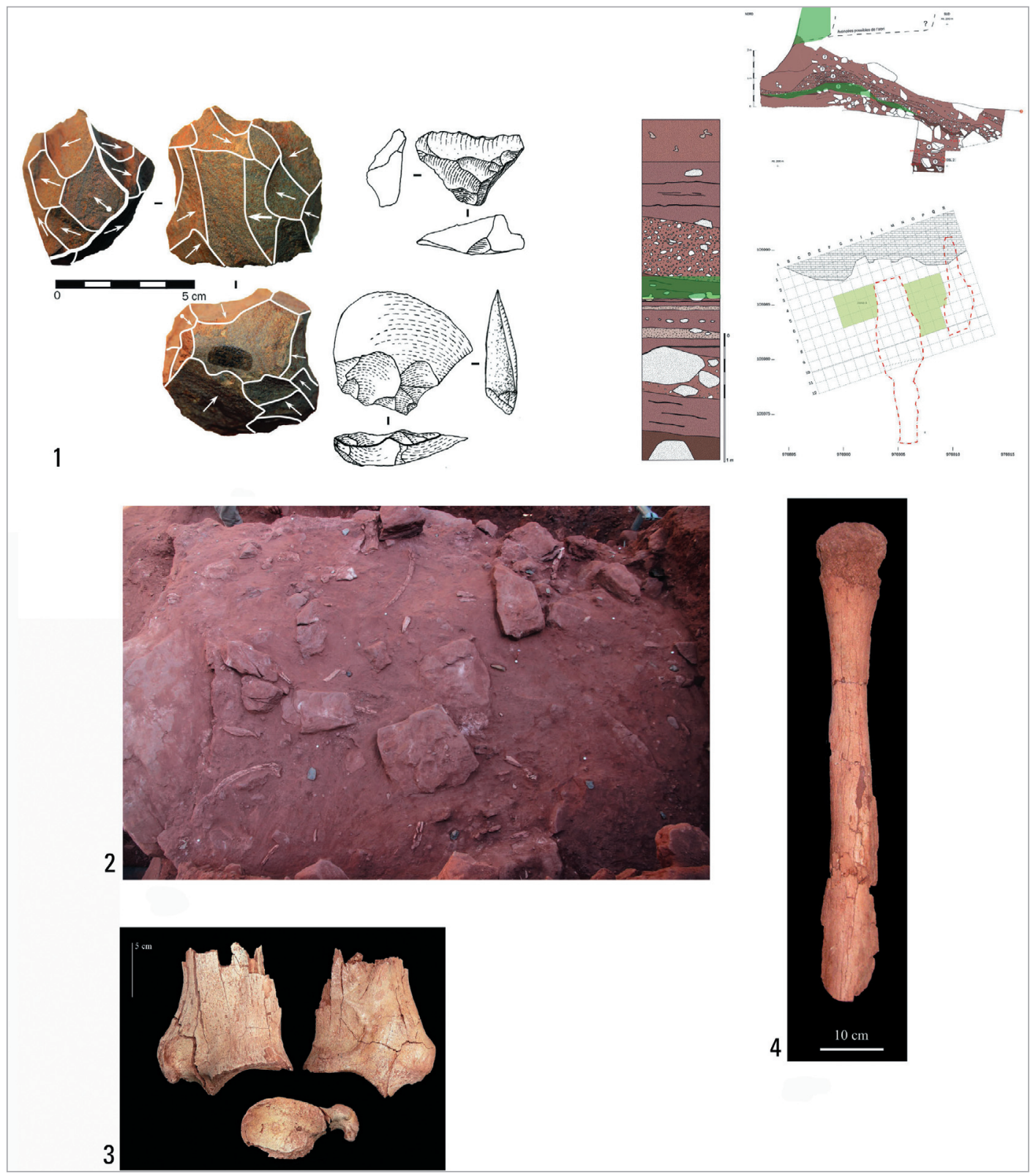

slope. The climate at the time was characterized by a period of thaw as revealed by geomorphological and anthropological studies. However, the study of the microfauna suggests a more severe climate (annual temperatures of 3.7 to $4.7^{\circ} \mathrm{C}$; Stoetzel in Koehler et al. 2016b). The occupations are sparse and the remains are fairly scant, suggesting that we are dealing with short-term occupations, perhaps influenced by the restricted size of the shelter (Fig. 6: 2).
Fig. 6.

Main results from Layer 5 .

1) lithic industry (discoidal and Kombewa cores; pseudo-Levallois point; S. Diemer); 2) view of Layer 5 during excavation (H. Koehler); 3) mammoth bone (femur; N. Sévêque); 4) horse scapula (N. Sévêque). 
A number of joints of meat, comprised principally of horse, reindeer and mammoth, were brought onto the site by the Neanderthals (Fig. 6: 3 and 4). These joints were specifically chosen for their nutritional value, with no single species predominating.

A possible hearth has been identified at the edge of the excavated area. It is composed only of wood charcoal, which, as we will see, differs from evidence in underlying levels. This might indicate a period of thaw during which forest cover would have been more significant in the area.

The lithic industry also differs slightly from what we find in the underlying levels in that the debitage is mainly discoidal and the dominant raw material is phtanite (Fig. 6: 1).

Therefore, all of the evidence seems to be pointing to short-term occupations, the purpose of which remains a mystery (possible stop-over sites).

\section{Layer 7A}

The occupations within Layer 7A took place in a shelter with a larger overhang than that described above (Fig. 7). They occurred in winter, in a period when the climate was more severe and when the boreal forest had given way to arid continental steppes.

The remains are much more numerous than in Layer 5 and are particularly dense in the western part of the excavated area. A possible hearth has been identified.

The lithic industry differs from that of the preceding layer. Flint is now dominant and the Levallois technique is the principal reduction technique employed (Fig. 7:2). In addition, studies of the micro-facies reveal a diversity of raw materials which might indicate longer periods of occupation. Finally, numerous edge-sharpening flint flakes have been found which are made of raw materials that do not occur among the tools recovered from the same layer. This suggests that tools were produced or re-sharpened in situ, and then carried away from the excavated area.

Numerous faunal remains, often poorly preserved, have been recorded in this level. Mammoth remains are numerically dominant, with all parts of the skeleton represented (Fig. 7: 1,3). In contrast, species such as horse and reindeer are less numerous and were brought to the site in the

Fig. 7 (right).

Main results from Layer 7A. 1) mammoth teeth (N. Sévêque); 2) lithic artifacts (refitting of two Levallois points; Levallois flake and core; refitting of flakes (S. Diemer); 3) mammoth rib with evisceration marks (N. Sévêque); 4) view of excavation of layer 7A (H. Koehler). form of joints of meat. While difficult to envisage, it appears that the Neanderthals came to the site in wintertime, bringing with them a number of joints of meat, and staying long enough to hunt and bring back to camp one or more complete mammoths. We cannot but ask ourselves how and why the transportation of mammoth carcasses took place. It must have involved a significant, organized, communal effort.

It is also interesting that most of the skull remains were concentrated in the western part of the excavation and appear to overlie lithic material (Fig. 8). Perhaps we are looking at a specific waste disposal or dump area. 
The Middle Paleolithic Occupations of Mutzig-Rain (Alsace, France)

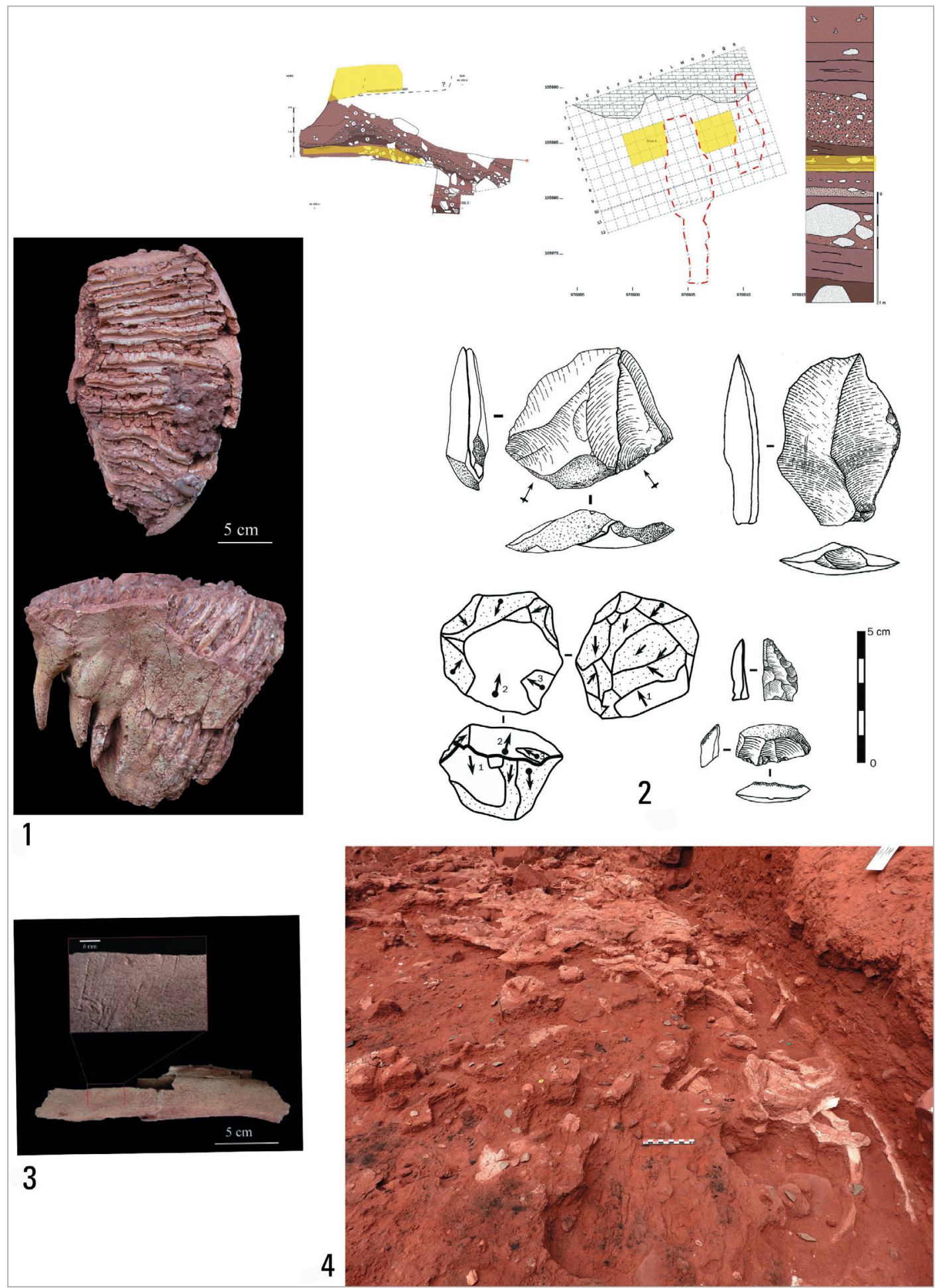




\section{Layer 7C1}

The occupations identified in the underlying layer, Layer 7C1, are somewhat different. These occurred during the summer, within the same rock overhang and probably under the same climatic conditions (Fig. 9). The microfauna suggest a possible period of thaw but this remains to be verified (Stoetzel in Koehler et al. 2016).

The lithic industry is once again dominated by the Levallois technique, but here the principal raw materials are coarse-grained magmatic rocks (Diemer in Koehler et al. 2016b; Diemer this volume; Fig. 9: 1).

Numerous large faunal remains have been recorded but they consist almost entirely of reindeer (Fig. 9: 3). Similar to the pattern observed in the overlying level, here again it would seem that meat from the less common species (such as horse and bison) was brought on site in the form of joints while the predominant species was brought in the form of entire carcasses (Sévêque in Koehler et al. 2016b and Sévêque 2017).

In terms of spatial distribution, specific concentrations of bone can be identified and are associated with quite a large hearth area (Fig. 10). This area of burning is almost entirely composed of burnt bone, which underlines the fact that bone was used as fuel. Paleoenvironmental analyses, particularly of the microfauna, do not indicate a total absence of forest cover in the area but suggest that plant-based fuel was scarce, which would have forced the Neanderthals to use sources other than wood.

In either case, the Mutzig site seems to have served as a rear basecamp for a summer reindeer slaughtering site. The carcasses were brought back to the base-camp where they were quickly processed.

\section{Layer 7C2}

Layer 7C2 is quite similar to that above it except that the climate appears to have been a little more severe (Fig. 11). The evidence points to the development of open environments, particularly cold continental steppes, but with occasional woodland refuges. Occupations were short-term and repeated, occurring throughout the year.

The lithic industry closely resembles that of the overlying level, i.e., mainly Levallois reduction technique using coarse-grained magmatic rocks (Fig. 11: 1).

However, the faunal remains consist almost exclusively of reindeer (Fig. 11:4). At least seven individuals have been identified in a $20 \mathrm{~m}^{2}$ area and they are essentially composed of females and their young. Once

Fig. 8 (right).

Spatial distribution of remains in Layer 7A (Wegmüller and Lutz, modified) showing principal remains found during 20142017 excavation and the vertical distribution of bones (red points) and lithics (blue points) in this layer. again, whole carcasses were brought on to the site and rapidly processed in situ. As of yet, we have not identified a hearth area in this level.

In terms of spatial distribution, occasional concentrations of bone can be observed, though they are not very obvious (Fig. 11: 2 and 3; Fig. 12: 1). However, this layer appears to continue downslope from the shelter. Here we found a jumble of reindeer bones that might suggest a disposal area (Fig. 12: 2). 


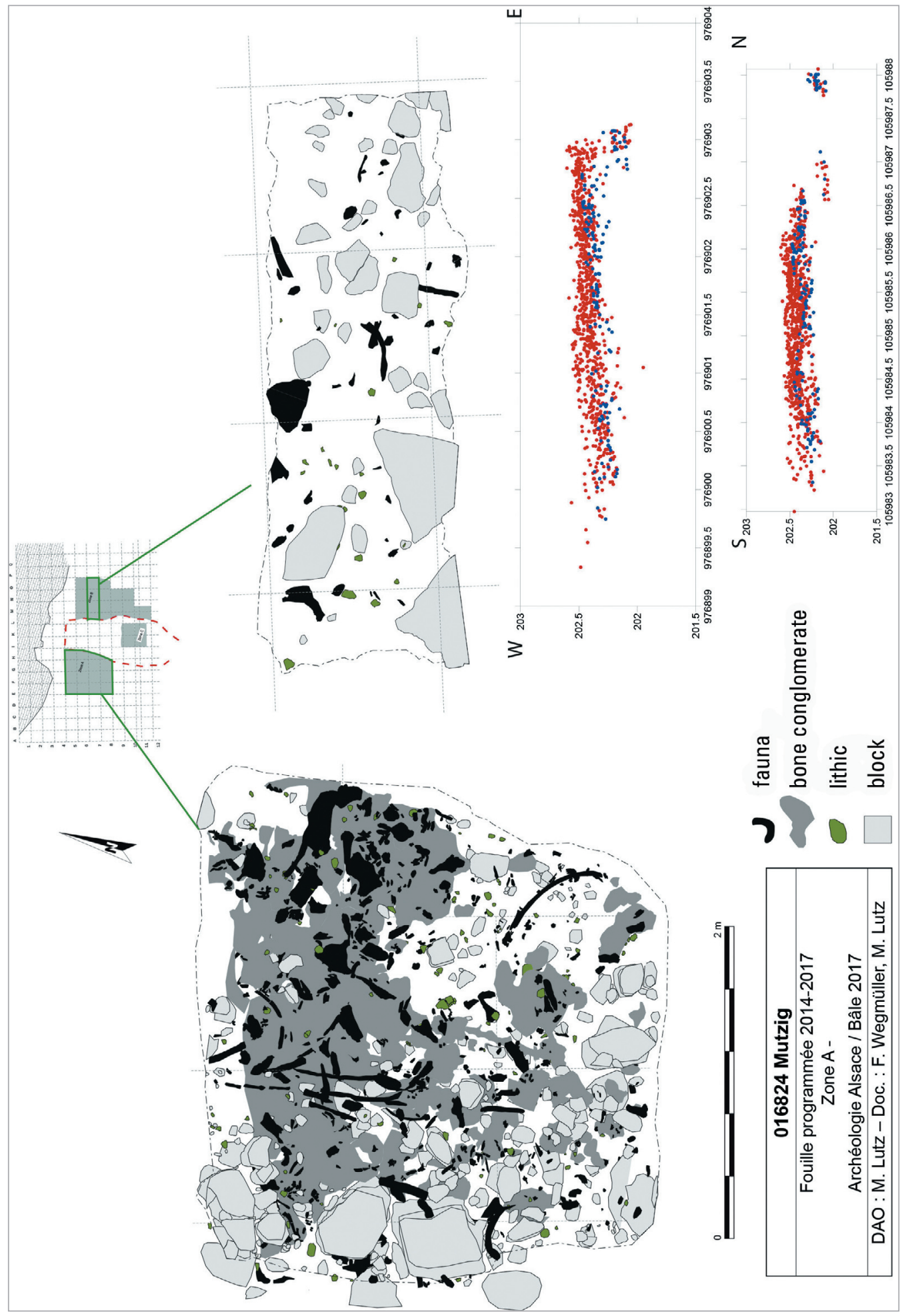




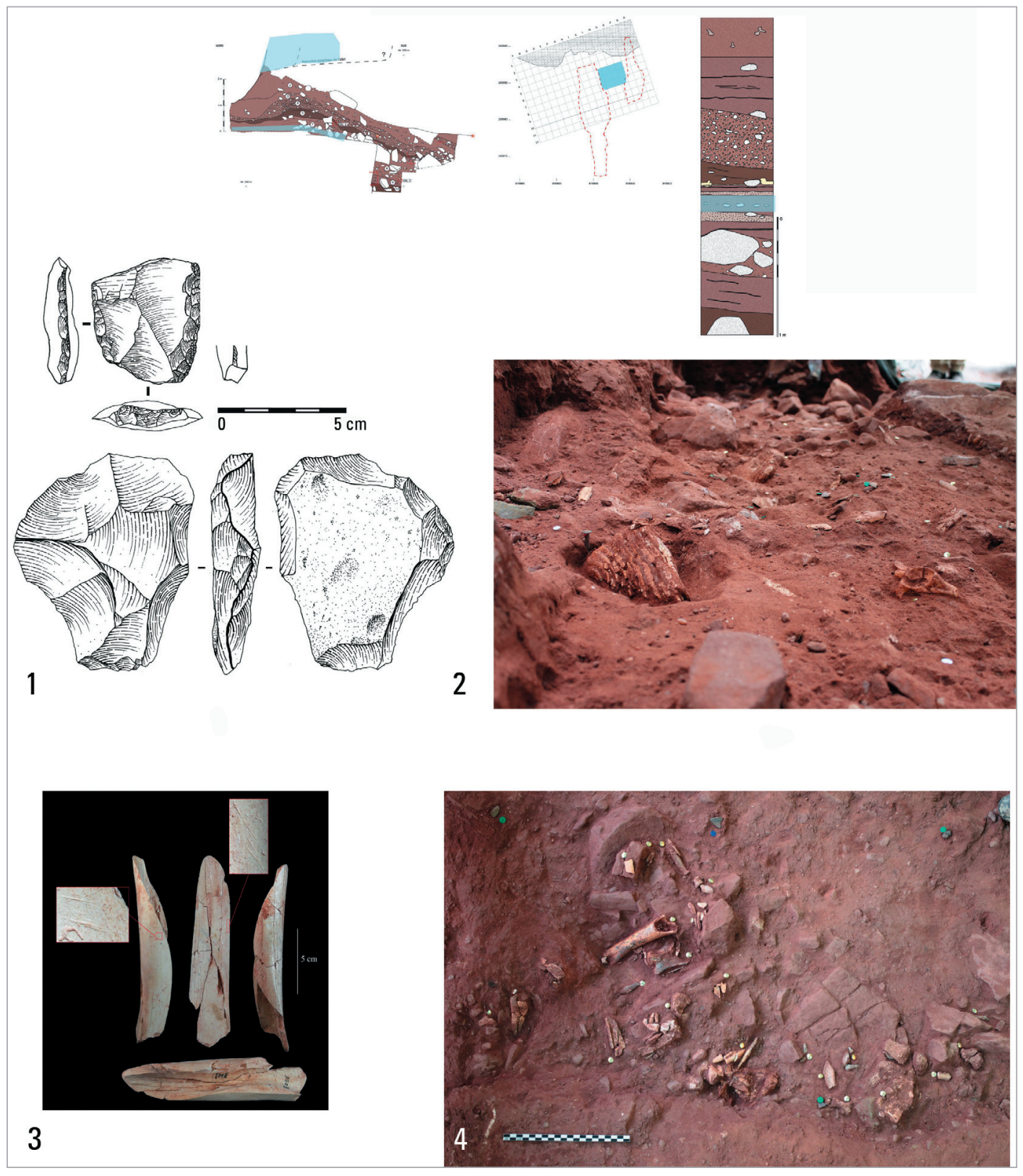

Fig. 9 (above).

Layer 7C1.

1) lithic artifact (sidescraper and Levallois core,

S. Diemer); 2 \& 4) Layer 7C1 during excavation

(H. Koehler and I. Déchanez-Clerc); 2) reindeer bone with cut marks (N. Sévêque).
Fig. 10 (right).

Spatial distribution of remains in layer 7C1 and hearth.

1) spatial distribution of remains (F. Wegmüller and M. Lutz); 2) hearth under excavation by "quarters" with detail (H. Koehler). 


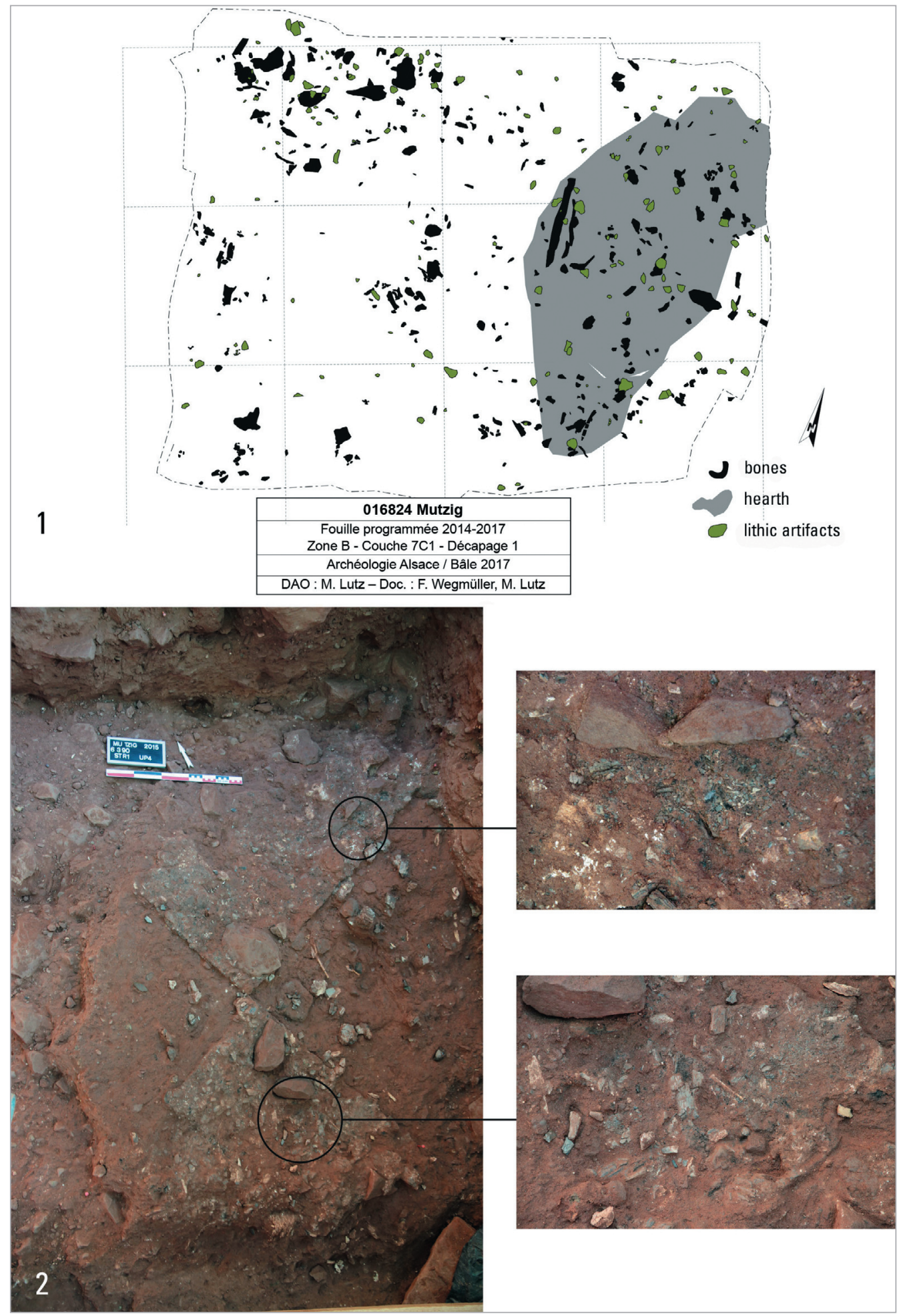




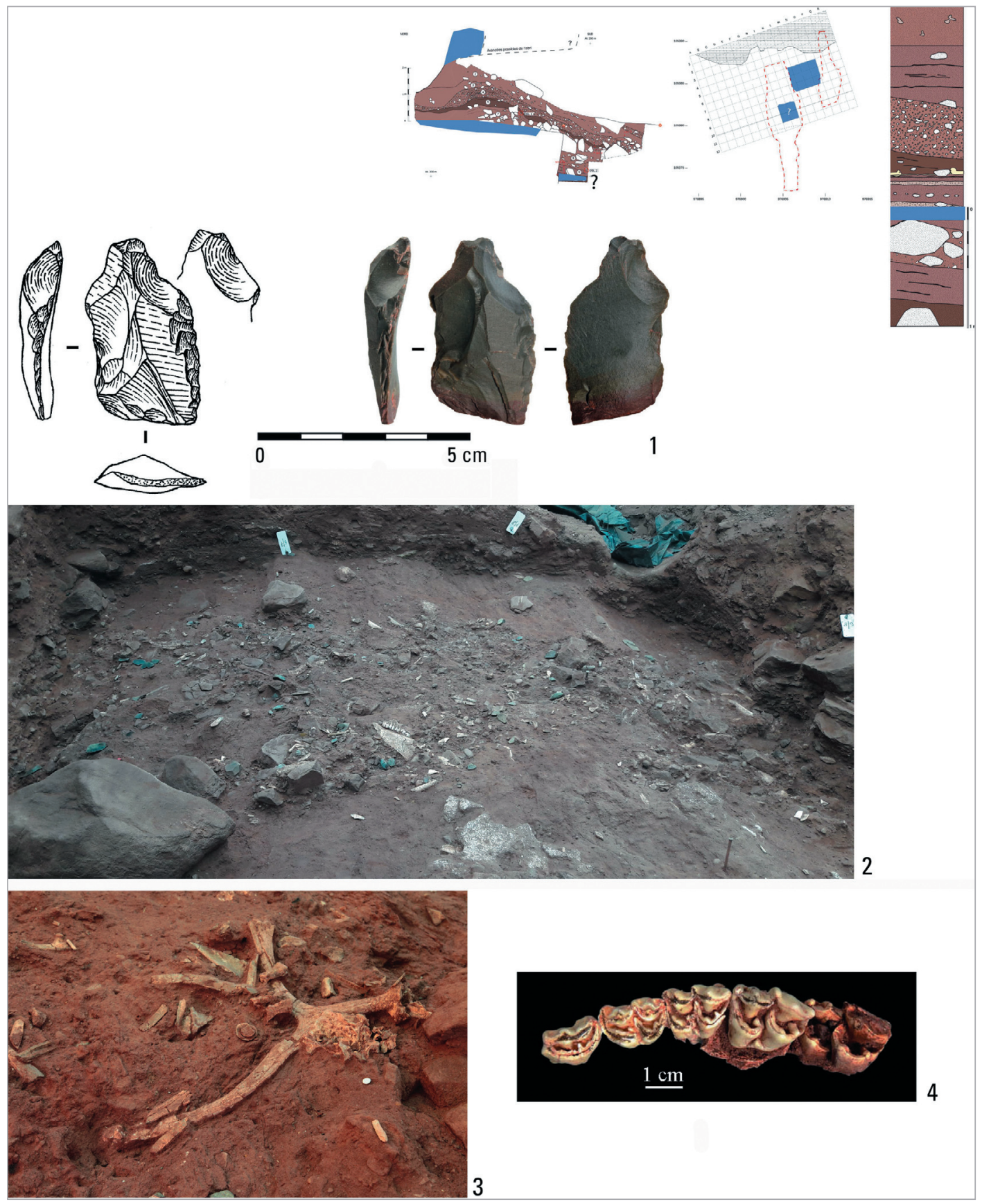

Fig. 11.

Layer 7C2.

1) lithic tool (S. Diemer); 2 and 3) Layer 7C2 under excavation (H. Koehler and F. Schneikert); 4) reindeer teeth (N. Sévêque). 


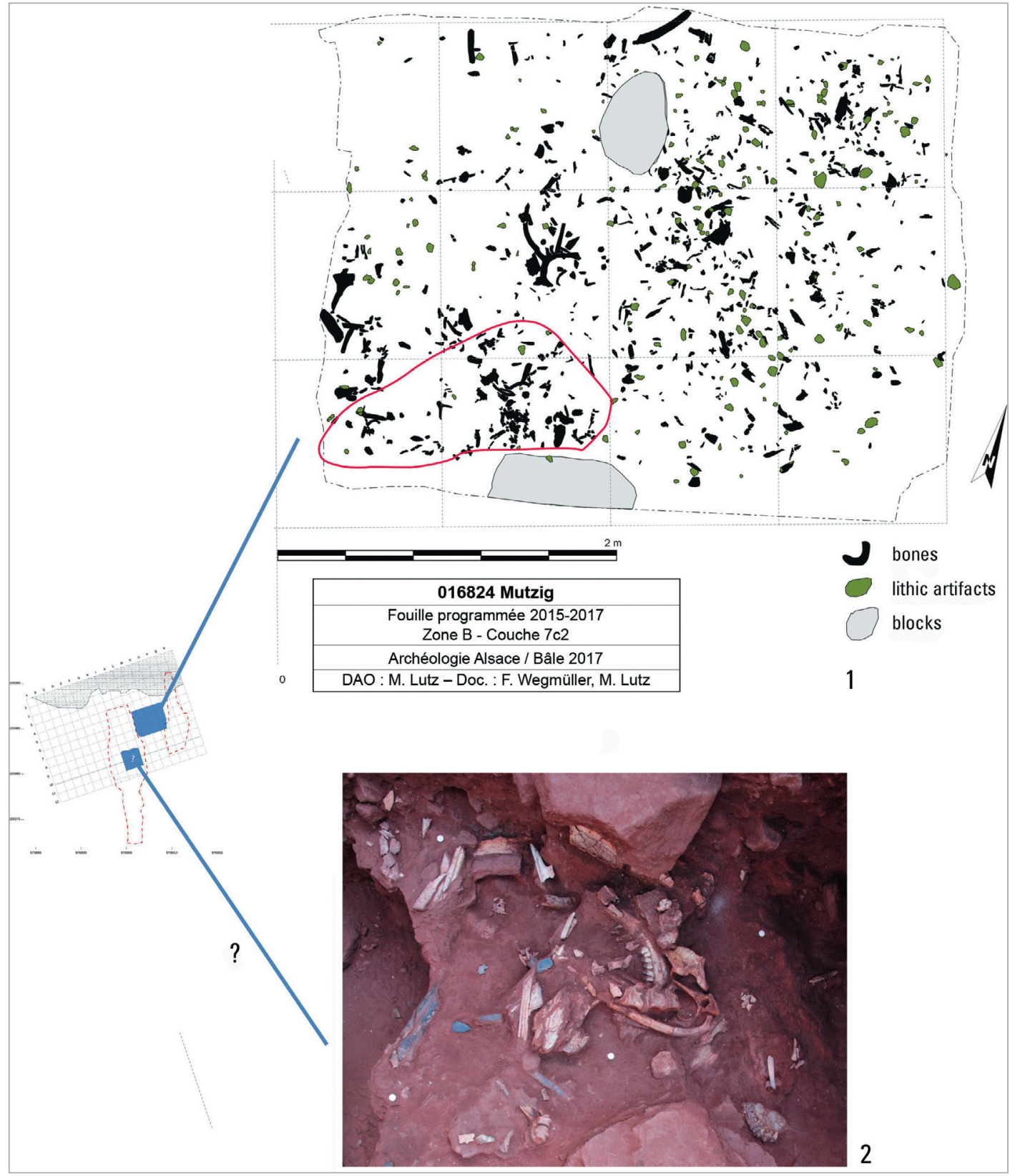

Fig. 12.

Spatial distribution of remains in Layer 7C2.

1) spatial distribution of remains in Layer 7C2 (F. Wegmüller and M. Lutz). In the areas marked by the red circle, we tend to have a predominance of leg bones of reindeer. 2) possible disposal area for reindeer bones downslope from the shelter (M. Al Najjar). 
For this level we appear to be dealing with very short occupations associated with specialized hunting of reindeer and the preliminary processing of their carcasses.

\section{Layers 9 and 10}

Finally, the deepest levels, which were exposed during testing at the foot of the shelter, appear to be very rich in finds and attest to a milder, more humid climate compared to the overlying layers. The microfauna indicate the significant presence of forest, particularly temperate forest, and mean annual temperatures that were estimated to have been above $6^{\circ} \mathrm{C}$ (Fig. 13).

Fig. 13.

Beaver bones found in Level 9/10 (N. Sévêque).

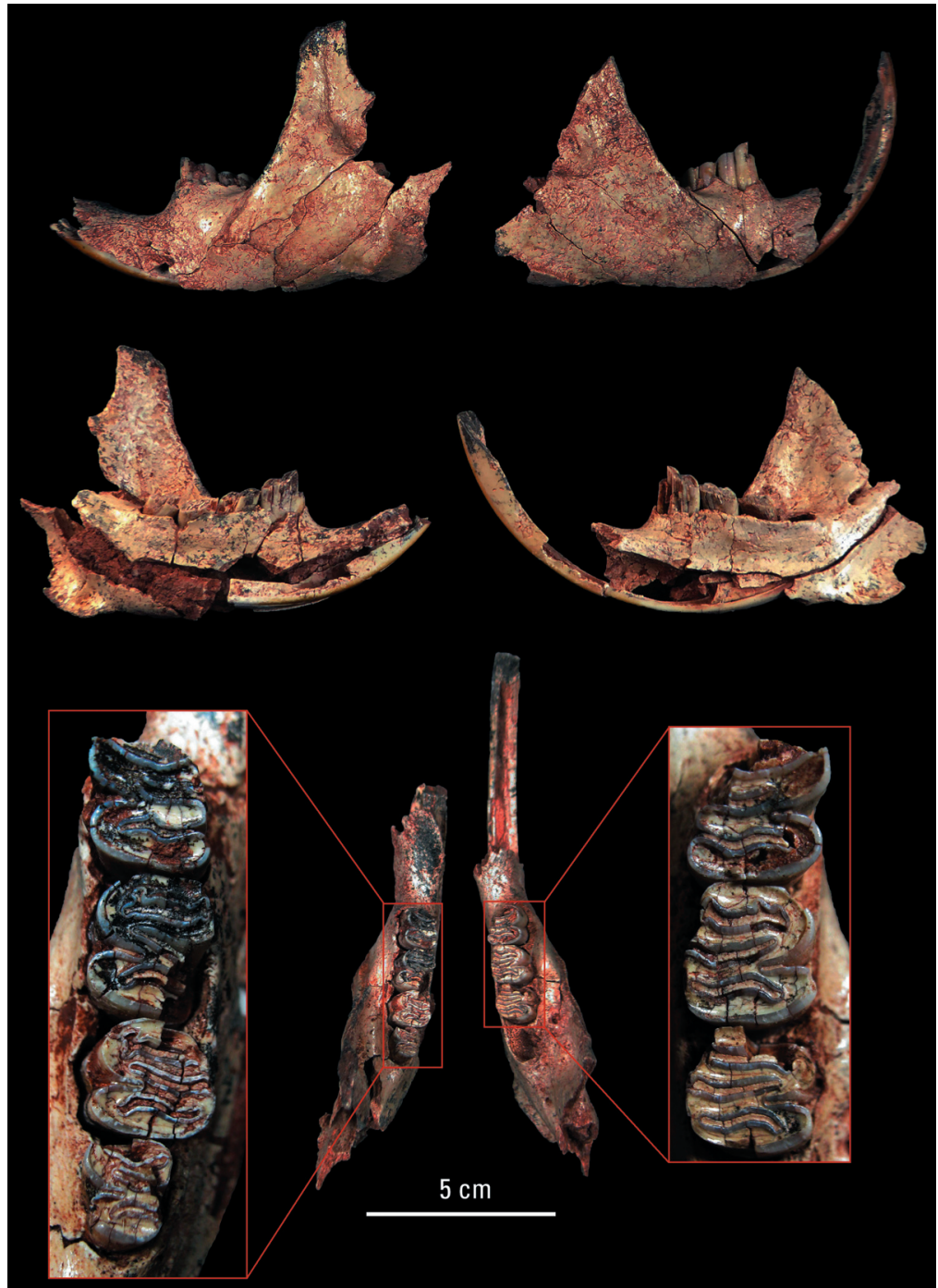

The Rhine During the Middle Paleolithic: Boundary or Corridor? 
The return of more temperate species is also observed in charcoal remains. The large fauna include species that also require a more wooded environment, notably beaver. However, steppe species, such as reindeer and mammoth, are also present.

It would be useful to determine whether this milder episode corresponds to the onset of the Eemian interglacial or if it reflects an interstadial at the beginning of the Ice Age. Likewise, it would be interesting to link these levels to those within the shelter, as we have been able to do for the upper level.

\section{CONCLUSION}

The Mutzig site clearly witnessed numerous repeated occupations during the early Weichselian. These occupations differ in terms of their function and operation but, regardless of the layer, the food acquisition strategies appear to have been highly organized, involving selective and/or specialized hunting. The processing of the meat appears to have been efficient, as illustrated by the lack of evidence for scavenging by carnivores within the bone assemblage.

The occupations appear to have been structured and may have formed part of an equally organized cycle of nomadism.

\section{LITERATURE}

Detrey, J., M. Guélat, T. Hauck, O. Putelat, P. Rentzel, D. Schuhmann, and T. Vigreux. 2009. Mutzig (Alsace, Bas-Rhin). Rain, boulevard Clémenceau. Rapport de sondage 2009. PAIR.

Forrer, R. 1930. Deux stations quaternaires à restes de Mammouths dans la région du grès vosgien, Gresswiller et Hermolsheim. Cahiers alsaciens d'art, d'archéologie et d'histoire 1930: 81-84.

Koehler, H., F. Wegmüller, J. Detrey, T. Hauck, J. J. Bahain, F. Basoge, H. Bocherens, E. Cornet, S. Diemer, D. Drucker, D. Hager, M. Lutz, M. Peillet, C. Pümpin, H. Richard, N. Seveque, E. Stoetzel, E. Tartar, and A. Vigneron. 2013. Mutzig-Rain, ungisement du Paléolithiquemoyen. Rapport de la campagne triennale de 2011-2012 et 2013. Service Régional d'Alsace.

Koehler, H., F. Wegmüller, J. Detrey, S. Diemer, T. Hauck, C. Pümpin, P. Rentzel, N. Seveque, E. Stoetzel, P. Wuscher, P. Auguste, H. Bocherens, M. Lutz, and F. Preusser. 2016a. Fouilles de plusieurs occupations du Paléolithique moyen à Mutzig-Rain (Alsace) : premiers résultats. Bull. Société Préhistorique Fr. 113 (3): 429-474.

Koehler, H., and F. Wegmüller, eds. 2016b. Mutzig, Bas-Rhin. Rain, Boulevard Clémenceau., Rapport de fouille programmée, triennale 2014-2016. Service régional de l'archéologie d'Alsace.

Sainty, J. 1992. Mutzig (Bas-Rhin). Sauvetage urgent 1992. Rapport de fouille. Direction régionale des affaires culturelles d'Alsace, Service régional de l'archéologie.

Sainty, J. 1993. Mutzig, les chasseurs de mammouths dans la vallée de la Bruche. Fouilles récentes en Alsace tome 2. Strasbourg: Les musées de la ville de Strasbourg. 
Koehler, Wegmüller, Audiard, et al.

Sainty, J., M. Oberkampf, T. Rebmann. 1994. Site préhistorique de Mutzig (Bas-Rhin). Rapport de prospection thématique de vallée moyenne de la Bruche. Année 1994. Direction Régionale des Affaires Culturelles d'Alsace. Strasbourg: SRA.

Sainty, J., T. Rebmann, and M. Oberkampf. 1996. Site préhistorique de Mutzig (Bas-Rhin). Prospection thématique de la moyenne vallée de la Bruche. Années 1994-1996. Direction régionale des affaires culturelles d'Alsace. Service régional de l'archéologie.

Sévêque, N. 2017. Variabilité des comportements alimentaires au Paléolithique moyen en France septentrionale - Apports des études archéozoologiques. Thèse de Doctorat de I'Université Lille 3.

Stoetzel, E., and S. Montuire. 2016. Les rongeurs, indicateurs des paléoclimats: Application aux assemblages de trois sites du Nord de la France. Quaternaire 27 (3): 227-238.

Stoetzel, E., H. Koehler, D. Cliquet, N. Sévêque, and P. Auguste. 2016. New Data on Late Pleistocene Small Vertebrates from Northern France. Comptes Rendus Palevol: 681-695. 